\title{
RANCANG BANGUN SISTEM INFORMASI MANAJEMEN ASET BERBASIS WEB UNTUK OPTIMALISASI PENELUSURAN ASET DI TEKNIK INDUSTRI UNDIP
}

\author{
Galih Setyo Pambudi, Sriyanto*), Ary Arvianto \\ Program Studi Teknik Industri, Fakultas Teknik, Universitas Diponegoro \\ Jl. Prof. H. Soedarto, SH. Semarang, Indonesia 50275
}

(Received: August 9, 2016 / Accepted: December 21, 2016)

\begin{abstract}
ABSTRAK
Program Studi Teknik Industri (PSTI) adalah salah satu jurusan di Fakultas Teknik Universitas Diponegoro. Pada tahun 2015 PSTI telah memiliki gedung baru sebagai sarana perkuliahannya. Seiring dengan hal itu PSTI juga mendapatkan aset-aset penunjang perkuliahan seperti komputer, meja, kursi dan lain-lain. Namun pengelolaan aset di PSTI saat ini tidak berjalan dengan baik, PSTI tidak mempunyai database aset khusus untuk mempermudah pengelolaan dan penelusuran asetnya. Pengelola aset di PSTI selama ini hanya menggunakan pendataan menggunakan Excel untuk mendata ketersediaan asetnya dan itu juga sudah lama tidak diperbarui. Banyak aset di PSTI yang tidak memiliki nomor inventaris yang telah di berikan oleh Unit Layanan Pengadaan (ULP) Fakultas Teknik. Hal ini menyebabkan susahnya melakukan penelurusan aset. Permasalahan ini sering menyebabkan pengelola aset di PSTI sulit untuk mengetahui kondisi aset itu baik, rusak maupun hilang. Hal tersebut membuat proses penggantian aset PSTI yang rusak di ULP menjadi tidak maksimal. Oleh karena itu, dibutuhkan suatu sistem informasi yang dapat menjalankan proses bisnis manajemen aset menjadi rapi dan terstruktur sehingga pengelola aset jurusan dapat dengan mudah untuk melakukan pengelolaan dan penelusuran aset. Proses perancangan Sistem Informasi Manajemen Aset (SIMA) dimulai dengan identifikasi sistem pengelolaan aset yang berjalan saat ini di PSTI dan membuat sistem baru yang diusulkan. Selanjutnya dari sistem usulan tersebut dirancang DFD (Data Flow Diagram) serta ERD (Entity Relationship Diagram) dan juga desain antarmuka sistem informasi tersebut. Dari tahap perancangan tersebut kemudian dihasilkan sebuah Sistem Informasi berbasis website untuk mengelola aset di PSTI. Selanjutnya dilakukan verifikasi dan validasi untuk mengetahui kesesuaian rancangan sistem dengan hasil akhir SIMA yang telah dibuat. Bagian akhir penelitian ini adalah membandingkan sistem lama dengan sistem baru untuk mengetahui perbedaan yang terlihat setelah diimplementasikannya sistem baru tersebut.
\end{abstract}

Kata kunci: aset; manajemen aset; sistem informasi

\begin{abstract}
Program Studi Teknik Industri (PSTI) is one of the departments in the Faculty of Engineering, University of Diponegoro. In 2015 PSTI has had a new building to support lesson activity. Along with it PSTI also get lectures supporting assets such as computers, desks, chairs and others. However, asset management in PSTI is currently not running well, PSTI has no special asset database to simplify the management and tracking of assets. PSTI asset manager at this time only use data collection using Excel to record the availability of its assets and it also had not updated. Many assets in PSTI do not have an inventory number that has been given by the Unit Layanan Pengadaan (ULP) Faculty of Engineering. This condition make difficult for searching their asset. These problems often lead to asset managers in the PSTI is difficult to determine the condition of the assets is good, broken or missing. This makes the process of replacing damaged assets PSTI in ULP be no maximum. Therefore, needed an information
\end{abstract}

\footnotetext{
${ }^{*}$ Penulis Korespondensi. email: sriyanto@undip.ac.id
} 
system that can run the asset management business into a neat and structured asset management department can be easy to perform management and asset tracking. The process of designing Asset Management Information System (SIMA) begins with the identification of an asset management system that is currently running in PSTI and make the proposed new system. Furthermore, of the proposed system is designed DFD (Data Flow Diagram) and ERD (Entity Relationship Diagram) and also the information system interface design. From the design stage and then produced a web-based information system to manage assets in PSTI. Further verification and validation to determine the suitability of the design of the system with the end result of SIMA have been made. Last is comparing the old system with a new system to determine the differences that looks after the implementation of the new system.

Keywords: asset; asset management; information systems

\section{Pendahuluan}

Perguruan tinggi sebagai salah satu organisasi yang memiliki proses bisnis yang sangat kompleks tentunya tidak akan menjalankan sistemnya secara manual, diperlukan pengimplementasian Computer Based Information System (CBIS) di segala unit yang berkepentingan guna mencapai efisiensi dan efektivitas dalam organisasi. Definisi CBIS merupakan sistem informasi yang diimplementasikan dengan menggunakan media teknologi komputer sebagai penunjang seluruh operasional yang berjalan dalam suatu organisasi (Rainer Jr. \& Cegielski, 2013). Secara umum, sebagian besar perusahaan/instansi tentunya telah memiliki sistem yang digunakan sebagai penunjang operasionalnya, dimana sistem tersebut terdiri dari sekumpulan komponen yang saling berinteraksi, bekerja sama dalam membentuk integrasi secara keseluruhan yang bertujuan untuk mencapai target tertentu (Belanger \& Slyke, 2012). Sistem informasi saat ini telah menjadi bagian penting dalam suatu organisasi guna menunjang operasional bisnis yang berjalan. Begitu juga halnya dengan Program Studi Teknik Industri (PSTI), Fakultas Teknik, Universitas Diponegoro dalam usaha untuk pengelolaan asetnya.

Aset adalah sumber daya ekonomi yang dikuasai dan/atau dimiliki oleh pemerintah sebagai akibat dari peristiwa masa lalu dan dari mana manfaat ekonomi dan/atau sosial di masa depan diharapkan dapat diperoleh, baik oleh pemerintah maupun masyarakat, serta dapat diukur dalam satuan uang, termasuk sumber daya nonkeuangan yang diperlukan untuk penyediaan jasa bagi masyarakat umum dan sumbersumber daya yang dipelihara karena alasan sejarah dan budaya (Lampiran II PP No 71 tahun 2010).

Aset merupakan modal penting dalam menunjang kinerja. Aset perlu diidentifikasi, dikelola, dan dirawat dengan baik, sehingga dapat digunakan dengan efektif dan efesien. Aset juga mendukung kegiatan operasional suatu instansi setiap harinya, tidak adanya informasi yang tepat untuk mengelola aset dapat menghambat kegiatan operasional. Kebutuhan informasi mengenai data dan informasi suatu aset sangatlah penting guna untuk memperbaiki kinerja di dalam sebuah instansi. Oleh karena itu, pada

Jurnal Teknik Industri, Vol. XI, No. 3, September 2016 masa sekarang sudah sangat dibutuhkan sebuah sistem pengelolaan aset yang bisa digunakan secara efektif.

Reyes (2015) mengimplementasikan sebuah sistem informasi pengelolaan dan pemeliharaan aset IT di kampusnya, Bulacan State University di Filipina. Sistem ini menyediakan manajemen dan pemantauan aset seperti peripheral komputer, furnitur dan peralatan kecuali untuk bahan habis pakai dan aset di perpustakaan seperti buku, tesis dan majalah karena tidak termasuk ruang lingkup sistem. Dari penelitian tersebut PSTI juga akan menerapkan sebuah sistem informasi yang akan menangani manajemen aset.

PSTI pada tahun 2015 telah memiliki gedung baru sebagai sarana perkuliahannya. Program Studi ini juga mendapatkan aset-aset penunjang perkuliahan seperti kursi, meja, papan tulis, dan lain-lain. Aset di PSTI pada umumnya dibagi menjadi dua yaitu barang inventaris dan barang habis pakai. Barang inventaris meliputi komputer, printer, kursi dan lain-lain sedangkan barang habis pakai berupa alat tulis kantor, flashdisk, spidol dan lain-lain. Namun saat ini PSTI belum memiliki sistem informasi internal untuk mengelola seluruh aset di gedung baru ini, sistem yang ada saat ini hanya terdapat di bagian Umum dan Pengelolaan Aset (UPA) Fakultas Teknik, Universitas Diponegoro yang mengelola semua aset jurusan seFakultas Teknik yaitu SIMAK BMN (Sistem Informasi Manajemen dan Akuntansi Barang Milik Negara).

PSTI saat ini hanya mempunyai data mengenai aset jurusan yang dibuat menggunakan Microsoft Excel. Masalah yang terjadi adalah data yang ada sudah usang dan sudah lama tidak di perbarui. Selain itu, penomoran inventaris setiap aset yang berasal dari ULP pun saat ini telah banyak yang hilang, rusak ataupun tidak terpasang, hal ini menyebabkan sulitnya melakukan penelurusan dan pengontrolan aset yang ada di PSTI. Permasalahan ini menyebabkan pengelola aset di PSTI sulit untuk melakukan pendataan kondisi aset itu baik, rusak maupun hilang. Hal tersebut membuat proses penggantian aset PSTI yang rusak di ULP menjadi tidak maksimal.

Solusi untuk mengatasi hal ini yaitu PSTI membutuhkan sebuah sistem informasi manajemen aset yang dapat menjalankan proses bisnis manajemen aset menjadi rapi dan terstruktur sehingga pengelola 
aset jurusan dapat dengan mudah untuk melakukan pengelolaan dan monitoring aset. Implementasi sistem informasi manajemen aset pada hakekatnya adalah upaya untuk tertib dokumen dan tertib administrasi pengelolaan aset. Tertib dokumen aset berkaitan dengan upaya penyediaan dan pendataan dokumen yang menyertai keberadaan aset, sedangkan tertib administrasi lebih dimaksudkan pada upaya membangun prosedur pengelolaan aset mulai saat pengadaan, perubahan data, hingga penghapusan aset (Hartono, 2010).

Penelitian ini akan merancang sebuah sistem informasi manajemen aset untuk optimalisasi penelusuran aset di PSTI. Rancangan sistem ini diharapkan dapat melengkapi berbagai kekurangan pada sistem yang lama dan dapat menciptakan kondisi tertib dokumen dan tertib administrasi pengelolaan aset.

Tujuan yang ingin dicapai pada penelitian adalah:

1. Melakukan identifikasi proses manajemen aset yang saat ini sedang berjalan di PSTI.

2. Merancang proses bisnis sistem manajemen aset baru yang lebih efisien untuk menggantikan sistem lama.

3. Menghasilkan prototype berupa sistem informasi manajemen aset berbasis website.

\section{Tinjauan Pustaka}

\section{Sistem Informasi}

Sistem informasi adalah suatu sistem didalam suatu organisasi yang mempertemukan kebutuhan pengolahan transaksi harian, mendukung operasi ,bersifat manajerial dan kegiatan strategi dari suatu organisasi dan menyediakan pihak luar tertentu dengan laporan-laporan yang diperlukan (Jogiyanto, 2005).

\section{Aset}

Aset adalah sumber daya yang mempunyai manfaat ekonomik masa datang yang cukup pasti atau diperoleh atau dikuasai/dikendalikan oleh suatu entitas akibat transaksi atau kejadian masa lalu (FASB, 1980).

\section{Sistem Informasi Manajemen Aset}

Sistem Informasi Manajemen Aset adalah sebuah aplikasi pengelolaan aset yang ditujukan untuk perusahaan besar atau BUMN dengan aset dengan jumlah banyak yang seharusnya memerlukan sebuah divisi sendiri untuk pengelolaan aset tersebut (Hartono, 2010).

\section{Diagram Konteks}

Diagram konteks adalah diagram yang terdiri dari suatu proses dan menggambarkan ruang lingkup suatu sistem (Bin Ladjamudin, 2005).

\section{Data Flow Diagram}

DFD (Data Flow Diagram) merupakan model dari sistem untuk menggambarkan pembagian sistem ke modul yang lebih kecil. (Bin Ladjamudin, 2005).

\section{Entity Relationship Diagram}

ERD adalah represenstasi dari suatu model organisasi secara detail, masuk akal dan digambarkan dalam bentuk grafik. ERD meruapakan model dari entity dalam suatu elemen bisnis, relasi antar entity dan atribut atau property dari entity dan relasinya (Valacich, 2004).

\section{Basis Data}

Basis Data adalah Kumpulan file/tabel/arsip yang saling berhubungan yang disimpan dalam media penyimpanan elektronis (Fathansyah, 2002).

\section{MySQL}

MySQL adalah sebuah "SQL client/ server relational database management system" yang berasal dari Scandinavia. Pada MySQL sudah termasuk SQL server, program client untuk mengakses server, halhal yang berguna dalam hal administrasi, dan sebuah "programming

interface" untuk menulis program sendiri (Setiabudi, 2002).

\section{Prototype}

Prototype merupakan suatu metode dalam pengembangan sistem yang menggunakan pendekatan untuk membuat sesuatu program dengan cepat dan bertahap sehingga segera dapat dievaluasi oleh pemakai. Metode ini memberikan ide bagi analis sistem atau pemrogram untuk menyajikan gambaran yang lengkap (Oetomo, 2002).

\section{Metode Penelitian}

Metode penelitian merupakan cara dan tahapan yang digunakan peneliti untuk melakukan penelitian mulai dari perumusan masalah sampai menemukan solusi dari permasalahan tersebut sesuai tujuan yang diinginkan. Dengan adanya tahapan-tahapan yang jelas yang saling terkait dan sistematik. Alur penelitian tersebut dapat dilihat pada gambar 1 . 


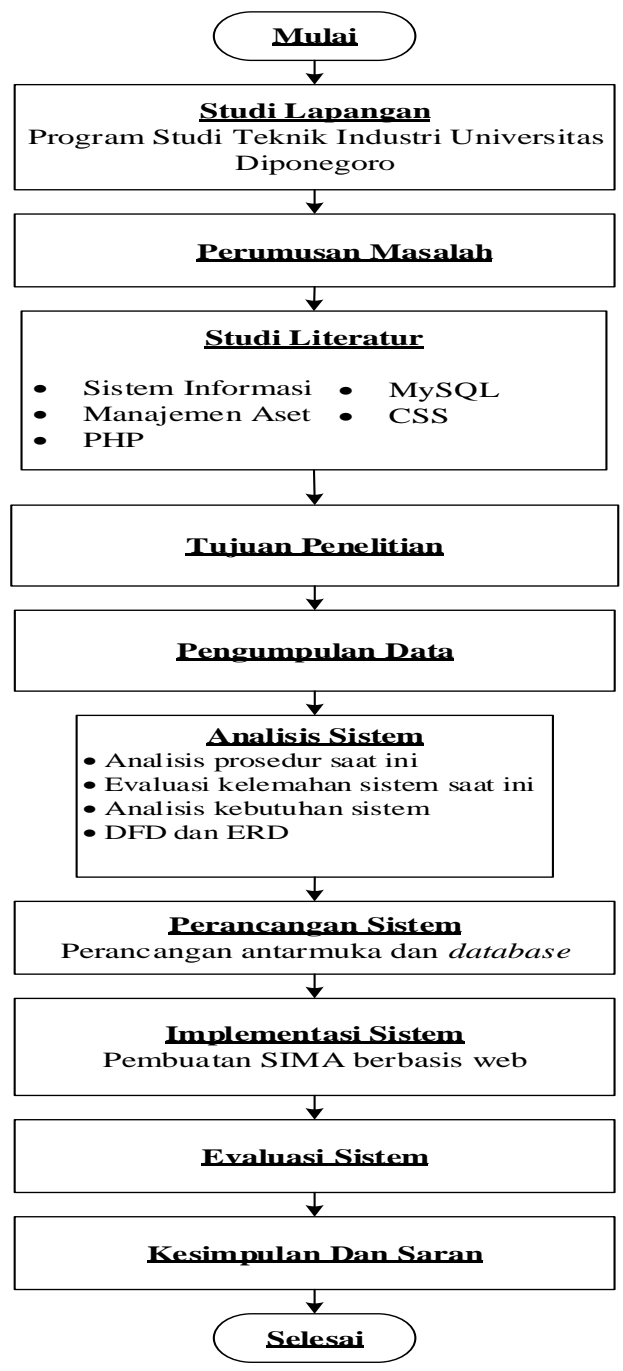

Gambar 1. Alur Penelitian

\section{Hasil Dan Pembahasan \\ Analisis Sistem Saat Ini}

Dalam sebuah instansi, tertib dokumen dan administrasi dalam pengelolaan segala urusan itu penting, termasuk diantaranya adalah pengelolaan aset. Pengelolaan aset di PSTI saat ini pada dasarnya belum berjalan baik karena PSTI belum memiliki sarana yang tepat untuk mengelola asetnya. Begitu juga dengan pengelola aset jurusan yang tidak memperhatikan tata kelola manajemen aset yang baik dari segi pendokumentasian setiap barang yang ada di PSTI.

Kelengkapan data sebuah aset di sebuah instansi itu penting karena akan digunakan sebagai gambaran di masa mendatang. Ketidaktertiban pencatatan aset menjadi kendala di PSTI dan sebagian jurusan lain di Fakultas Teknik UNDIP. Hal ini sangat menyulitkan untuk membangun sistem yang baik dalam pengelolaan aset di Fakultas Teknik terutama di PSTI. Pengkodean nomor inventaris yang dilakukan oleh

Jurnal Teknik Industri, Vol. XI, No. 3, September 2016
ULP Fakultas Teknik untuk setiap aset di PSTI sudah banyak yang hilang, maupun tidak terpasang di aset tersebut, hal ini membuat sulitnya untuk melacak aset yang ada sesuai dengan data pengadaan.

\section{Evaluasi Sistem Saat Ini}

Dengan mempelajari sistem yang berjalan, berikut merupakan permasalahan yang ada mengenai pengelolaan aset di teknik industri UNDIP:

a. Fakultas Teknik tidak memberikan software khusus bagi masing masing jurusan untuk mengelola asetnya, dalam hal ini pada khususnya adalah PSTI.

b. Proses pendokumentasian aset di PSTI masih menggunakan spreadsheet pada Microsoft Excel sehingga sulit untuk mendata secara rinci dengan tampilan yang bagus.

c. Sistem pendataan spreadsheet saat ini hanya menyediakan pendataan untuk aset aset tertentu saja dan tidak mendetail sesuai dengan kategorinya.

d. Pengaplikasian nomor inventaris yang diberikan oleh ULP tidak terkelola dengan baik.

e. Sistem yang ada saat ini belum menyediakan pendataan terkait barang habis pakai sehingga pegawai selalu menganggap sisa habis pada akhir bulan, padahal belum pasti pada akhir bulan semua stok barang habis pakai itu habis.

\section{Analisis Kebutuhan}

Analisis kebutuhan dari Sistem Informasi ini dilakukan dengan mengidentifikasi kebutuhan sistem, aktivitas yang terjadi pada sistem dan pihak yang terlibat dalam aktivitas pada sistem. Berikut merupakan analisis kebutuhan sistem informasi:

1. Dibutuhkan sistem yang dapat menginputkan data aset inventaris dan barang habis pakai.

2. Dibutuhkan pengelola khusus aset laboratorium

3. Dibutuhkan sistem yang dapat menempatkan aset sesuai dengan lokasinya

4. Dibutuhkan sistem yang dapat membedakan aset yang baik, rusak, diperbaiki, dan aset terhapus.

5. Dibutuhkan sistem yang dapat membuat penjadwalan kegiatan maintenance dan stok opname.

6. Dibutuhkan sistem yang dapat mengurutkan /sorting data aset berdasarkan kategori dan tahun pengadaan.

7. Dibutuhkan sistem yang dapat mencetak laporan data aset dalam bentuk pdf.

\section{Identifikasi Entitas}

Berikut merupakan deskripsi dari pihak yang terlibat dalam sistem:

1. Administrator, pihak dari jurusan yang memiliki akun dalam sistem dan memiliki tugas untuk mengedit data pengguna dan data lokasi serta mengelola event di SIMA. 
2. Admin Kantor, pengguna sistem sebagai admin kantor yang memiliki akun dalam sistem. Akun admin kantor di kelola oleh pengelola aset PSTI. Admin kantor akan mendata keseluruhan aset di teknik industri kecuali aset di laboratorium.

3. Admin Laboratorium, pengguna sistem sebagai admin laboratorium yang memiliki akun dalam sistem. Akun admin laboratorium akan di kelola oleh asisten masing-masing laboratorium yang ada di PSTI. Admin Laboratorium akan mendata keseluruhan aset di laboratorium teknik industri.

4. Manajer, pengguna sistem sebagai manajer yang memiliki akun dalam sistem. Akun manajer akan diisi oleh Ketua Jurusan. Pengguna ini dapat mengakses seluruh data aset di teknik industri yang di inputkan oleh admin kantor dan admin laboratorium. Dan dapat mencetak laporan data aset sesuai dengan kebutuhan.

\section{Context Diagram}

Diagram konteks SIMA terdiri dari empat entitas yang berperan yaitu administrator sebagai pengelola sistem informasi, admin kantor dan admin laboratorium sebagai pihak yang bertugas mendata aset, serta manajer selaku pengawas dalam sistem yang dikelola oleh ketua jurusan PSTI. Gambar 2 menunjukkan diagram konteks SIMA.

\section{Data Flow Diagram (DFD)}

Gambar 3 menunjukkan DFD dari SIMA. Terdapat empat proses utama yang terbentuk dari dekomposisi diagram konteks yaitu kelola data awal, kelola informasi, transaksi aset, dan kelola laporan.

\section{Entity Relationship Diagram (ERD)}

Gambar 4 menunjukkan ERD dari SIMA. Entitas pada ERD ini merupakan data store dari DFD yang telah dibuat sebelumnya.

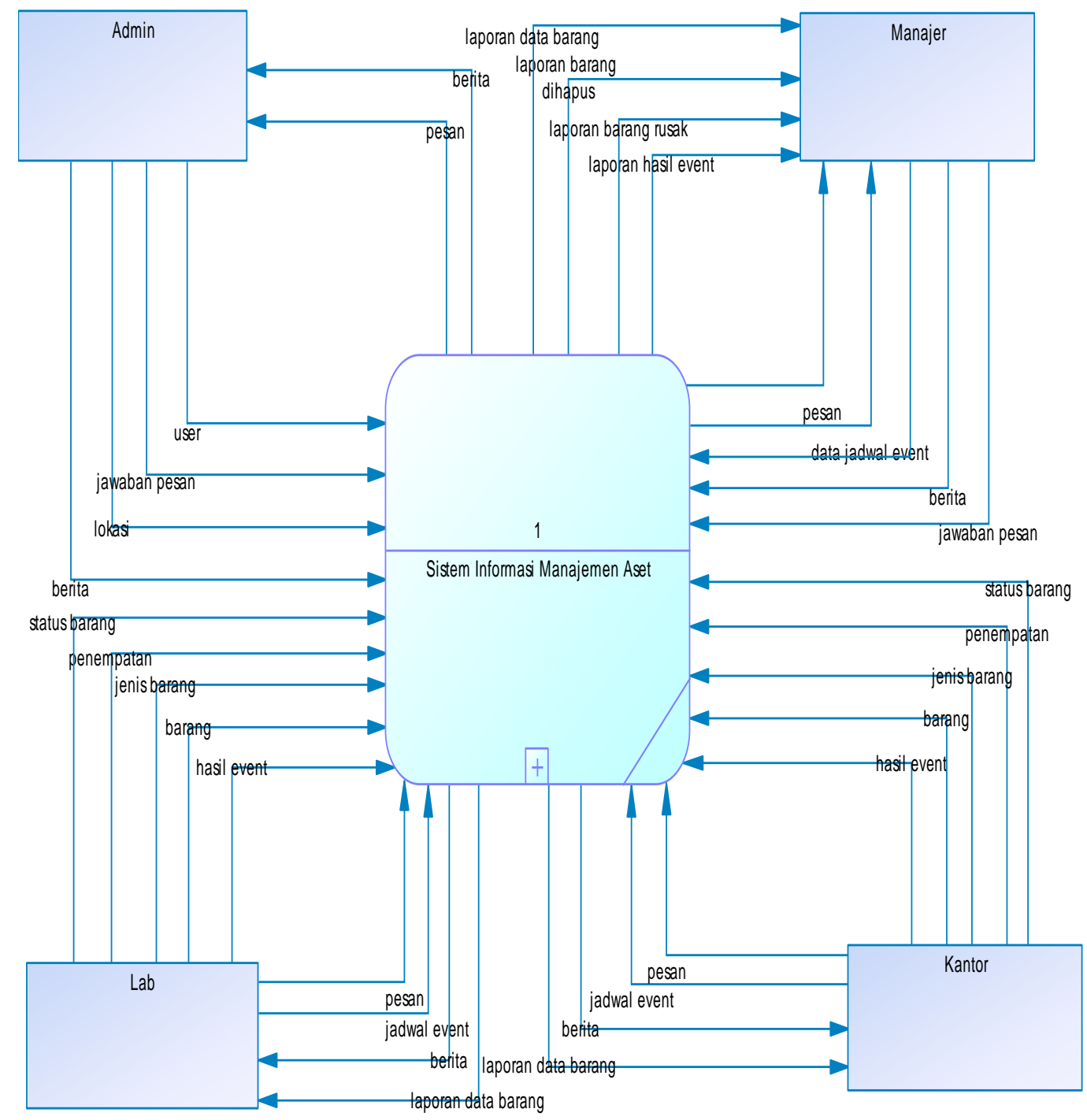

Gambar 2. Context Diagram 


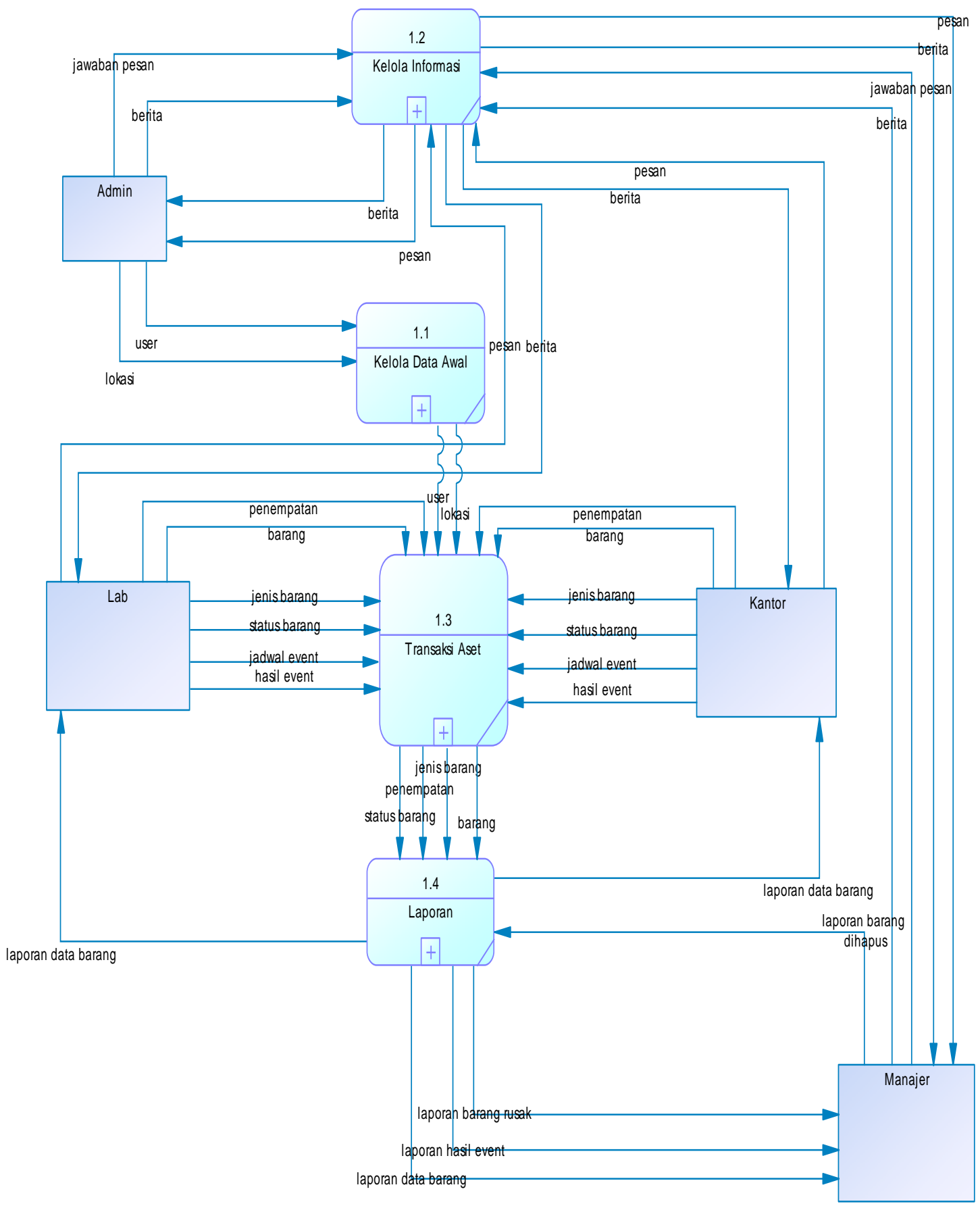

Gambar 3. Data Flow Diagram 


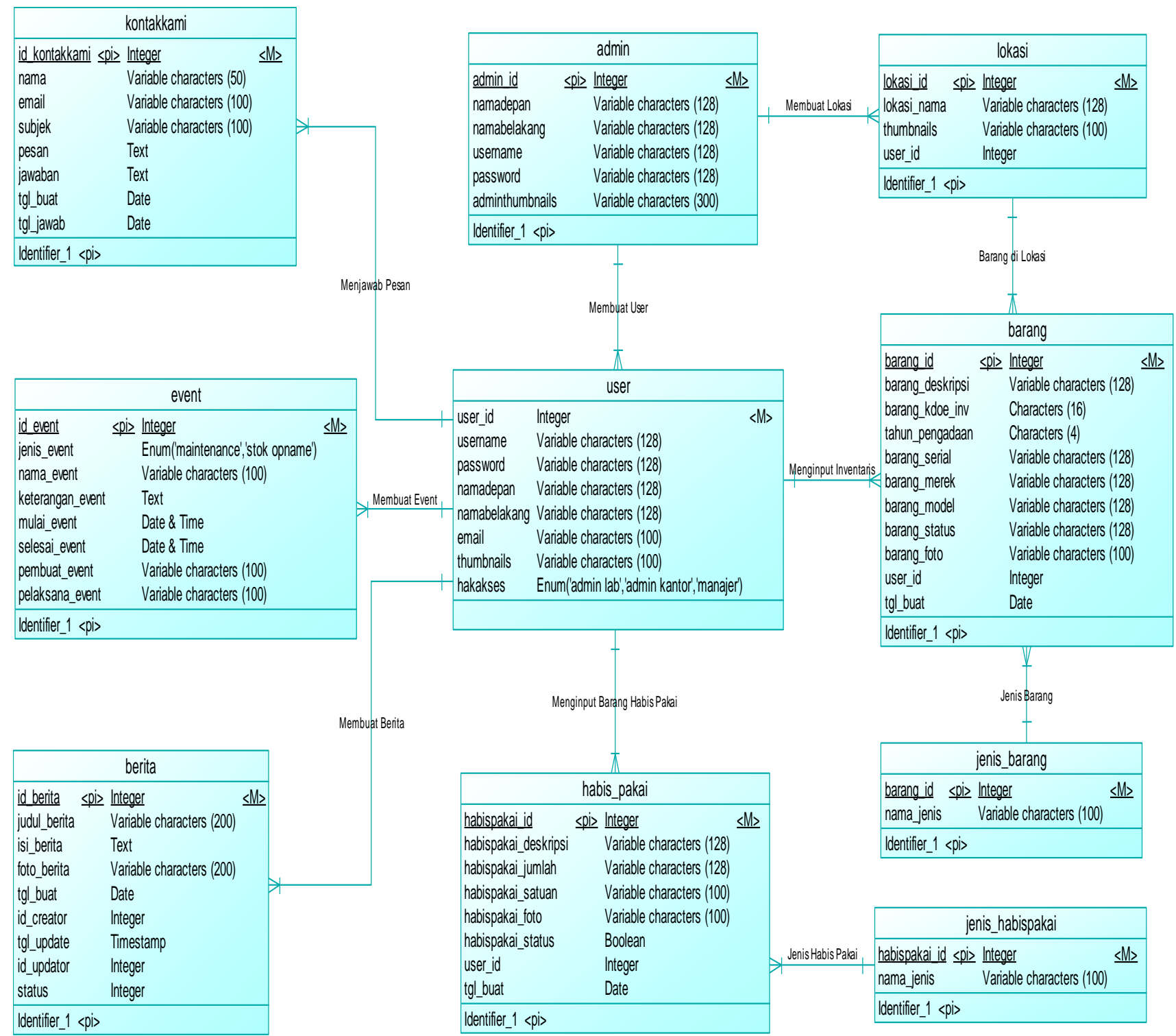

Gambar 4. Entity Relationship Diagram

\section{Antarmuka Website}

1. Halaman Utama

Gambar 5 menunjukkan halaman utama dari Sistem Informasi Manajemen Aset TI. Pada halaman utama ini terdapat form login untuk masuk ke sistem informasi. Terdapat empat jenis pengguna yang dapat mengakses sistem ini yaitu administrator, manajer, admin kantor dan admin laboratorium. Masing-masing pengguna akan memiliki hak akses yang berbeda sesuai dengan tugas dan wewenang dari jabatan pengguna sistem. Selain form login, juga terdapat halaman berita dan pengumuman, tentang aplikasi dan kirim pesan.

2. Halaman Pengelolaan Lokasi

Halaman berikutnya adalah halaman pengelolaan lokasi yang menampilkan menu pengelolaan lokasi atau ruangan, dalam menu ini adminstrartor dapat menambah, menghapus, atau mengedit lokasi atau ruangan sesuai dengan penanggungjawab masingmasing seperti ditunjukkan pada gambar 6 .

3. Halaman Beranda Administrator

Halaman beranda administrator menampilkan menu pengelolaan pengguna, lokasi, event dan berita. Pada menu pengguna, administrator dapat menambah atau menghapus data pengguna sistem informasi manajemen aset. Menu lokasi atau ruangan merupakan menu untuk mengatur letak dan banyaknya ruangan.

Selanjutnya menu event yaitu menu untuk mengatur kegiatan-kegiatan seputar manajemen aset seperti maintenance, menu berikutnya yaitu menu berita untuk memperbarui informasi terakit dengan pengelolaan aset di teknik industri, dan yang terakhir ialah menu pesan yang berguna 
untuk menjawab pesan dari user lain seperti pada gambar 7.

4. Halaman Kelola Barang Inventaris

Halaman Kelola Barang Inventaris berfungsi untuk mencatat data rinci per item barang inventaris. Di menu ini juga terdapat nomor inventaris yang terbentuk secara otomatis supaya setiap barang mempunyai nomor ID agar mudah di identifikasi. Selain itu juga tercantum jenis barang, deskripsi, merek, model, serial number, lokasi dan juga status yang dapat dikelola oleh admin kantor. Admin dapat menambah, mengedit, menghapus dan juga mencetak laporan data barang yang ada seperti pada gambar 8 .

5. Hasil Cetak Laporan Data Aset

Halaman ini dapat di generate oleh user manajer/ketua jurusan untuk mendapatkan file $p d f$ untuk cetak data laporan aset yang dibutuhkan seperti pada gambar 9 .

\section{Kebutuhan Spesifikasi Minimum}

Kebutuhan spesifikasi minimum pada SIMA terdiri dari kebutuhan spesifikasi minimum untuk perangkat keras (hardware) dan perangkat lunak (software).

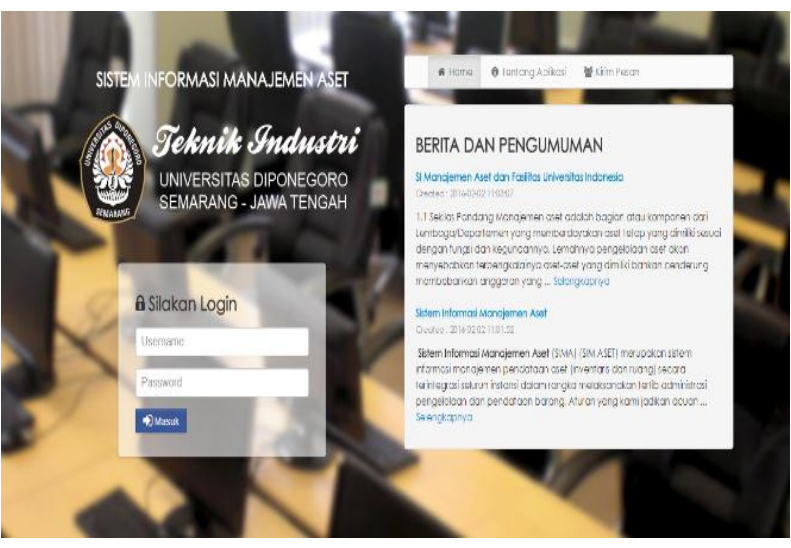

Gambar 5. Halaman Utama

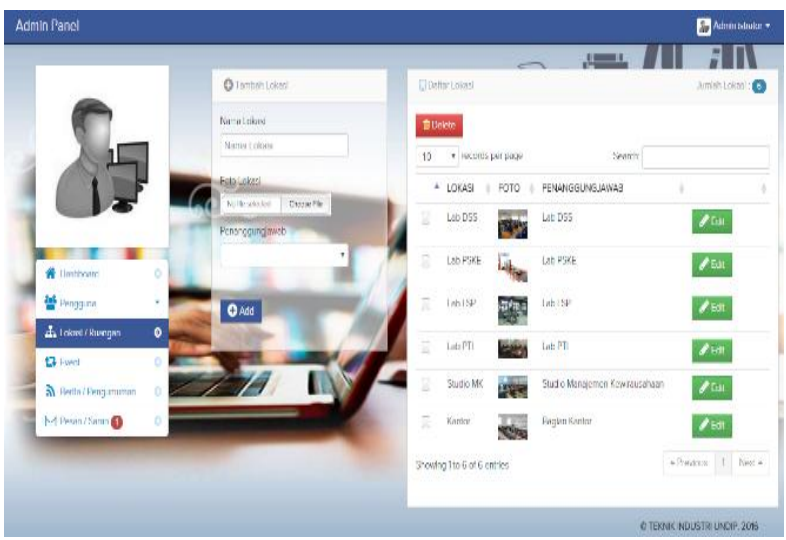

Gambar 6. Halaman Pengeloaan Lokasi

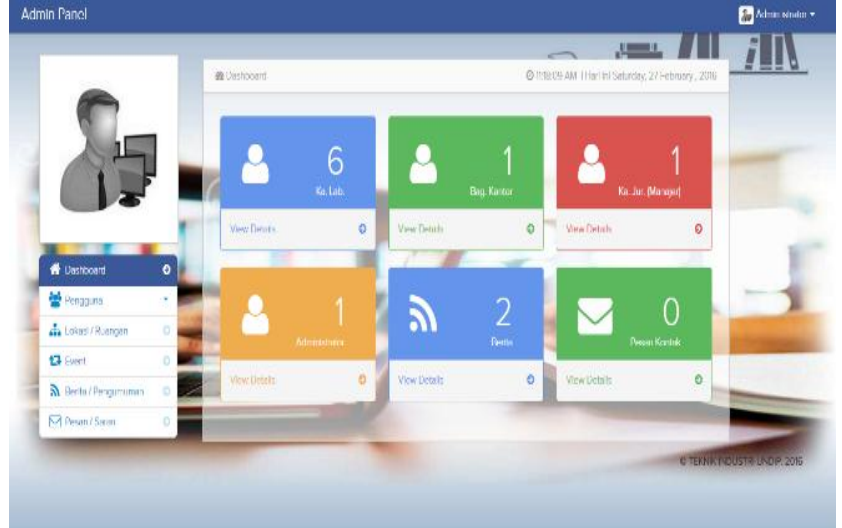

Gambar 7. Halaman Beranda Administrator

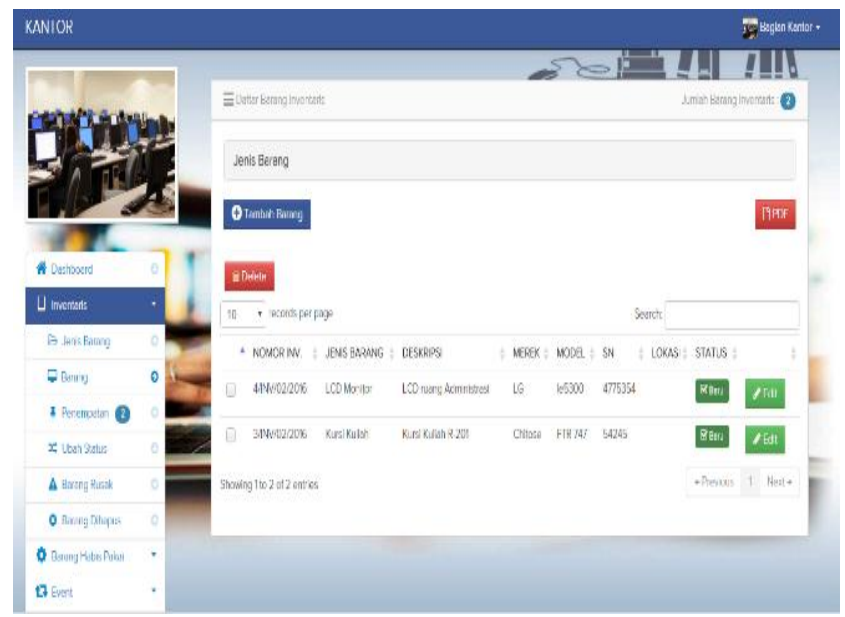

Gambar 8. Halaman Data Barang Inventaris

SISTEM INFORMASI MANAJEMEN ASSET

FAKULTAS TEKNIK UNIVERSITAS DIPONEGORO PROGRAM STUDI TEKNIK INDUSTRI

LAPORANDATA BARANG INVENTARIS

\begin{tabular}{|c|c|c|c|c|c|c|}
\hline \multicolumn{2}{|c|}{$\begin{array}{l}\text { Lokasi } \\
\text { Penanggung Jawab }\end{array}$} & \multicolumn{2}{|c|}{$\begin{array}{l}\text { : Kantor } \\
\text { : Baggian Kantor }\end{array}$} & $\begin{array}{l}\text { Jenis Barang } \\
\text { Tanggal Cetak }\end{array}$ & \multicolumn{2}{|c|}{ : Semua Jenis Barang } \\
\hline $\mathrm{N}_{0}$ & Kode Inv. & Nama Barang & Modd & Merek & Serial Number & Status \\
\hline 1 & 3/NVN022016 & Kursi Kuliaht & FTR 747 & Chilose & 54245 & Banu \\
\hline 2 & 4INV02/2016 & LCD Monitor & 103300 & $L G$ & 4775334 & Dhinpus \\
\hline
\end{tabular}

Gambar 9. Hasil Laporan Data Aset

\section{Kebutuhan Hardware}

Untuk dapat menjalankan Sistem Informasi ini, kebutuhan minimum hardware yang diperlukan untuk menunjang sistem adalah perangkat keras komputer 
PC kompatibel dengan spesifikasi yang disebutkan dibawah ini:
1. Prosesor
: berkecepatan 1,65 Ghz
2. RAM
: $1 \mathrm{~GB}$
3. Harddisk : $40 \mathrm{~GB}$
4. Keyboard, monitor, dan mouse

\section{Kebutuhan Software}

Sedangkan kebutuhan software yang digunakan pada sistem komputer untuk menjalankan SIMA adalah sebagai berikut:

1. Sistem Operasi Windows XP atau versi yang lebih tinggi

2. Xammp versi 1.7 atau versi yang lebih tinggi sebagai web server

3. Database MySQL

4. Web Browser

\section{Perbandingan Sistem Lama dengan Sistem Baru}

Berikut ini merupakan perbandingan antara sistem lama dengan sistem yang di rancang dalam penelitian ini.

Tabel 1. Perbandingan Sistem Lama dan Sistem Baru

\begin{tabular}{|c|c|c|}
\hline $\begin{array}{l}\text { Faktor } \\
\text { Pembanding }\end{array}$ & $\begin{array}{l}\text { Sistem } \\
\text { Sekarang }\end{array}$ & $\begin{array}{l}\text { Sistem yang } \\
\text { dirancang }\end{array}$ \\
\hline $\begin{array}{l}\text { Media } \\
\text { pencatatan\& } \\
\text { penyimpanan }\end{array}$ & $\begin{array}{l}\text { Menggunaka } \\
\text { n excel }\end{array}$ & $\begin{array}{l}\text { Database online } \\
\text { dengan sistem } \\
\text { informasi } \\
\text { berbasis web }\end{array}$ \\
\hline $\begin{array}{l}\text { Pendataan } \\
\text { aset } \\
\text { laboratorium }\end{array}$ & $\begin{array}{l}\text { Belum ada } \\
\text { pendataan } \\
\text { daftar aset } \\
\text { laboratorium }\end{array}$ & $\begin{array}{l}\text { SIMA menye- } \\
\text { diakan tempat } \\
\text { untuk mendata } \\
\text { semua aset yang } \\
\text { ada di enam } \\
\text { laboratorium } \\
\text { PSTI }\end{array}$ \\
\hline $\begin{array}{l}\text { Pendataan } \\
\text { barang habis } \\
\text { pakai }\end{array}$ & $\begin{array}{l}\text { Belum ada } \\
\text { pendataan } \\
\text { barang habis } \\
\text { pakai }\end{array}$ & $\begin{array}{l}\text { SIMA menye- } \\
\text { diakan tempat } \\
\text { untuk mendata } \\
\text { daftar barang } \\
\text { habis pakai } \\
\text { sesuai dengan } \\
\text { kuantitasnya dan } \\
\text { dapat di perbarui } \\
\text { setiap saat. }\end{array}$ \\
\hline $\begin{array}{l}\text { Cetak laporan } \\
\text { daftar barang }\end{array}$ & $\begin{array}{l}\text { Laporan } \\
\text { dapat di } \\
\text { cetak dari } \\
\text { data yang } \\
\text { ada di excel }\end{array}$ & $\begin{array}{l}\text { Laporan daftar } \\
\text { barang, barang } \\
\text { rusak, barang } \\
\text { dihapus dapat di } \\
\text { cetak sesuai } \\
\text { dengan jumlah } \\
\text { yang ada saat } \\
\text { kondisi tersebut }\end{array}$ \\
\hline
\end{tabular}

\begin{tabular}{|c|c|c|}
\hline $\begin{array}{l}\text { Pengawasan } \\
\text { dari ketua } \\
\text { jurusan } \\
\text { melalui user } \\
\text { manager }\end{array}$ & $\begin{array}{l}\text { Belum ada } \\
\text { media } \\
\text { pengawasan } \\
\text { yang } \\
\text { memudahka } \\
\text { n ketua } \\
\text { jurusan } \\
\text { untuk } \\
\text { mengetahui } \\
\text { keadaan } \\
\text { aset. }\end{array}$ & $\begin{array}{l}\text { SIMA menye- } \\
\text { diakan user } \\
\text { manajer yang } \\
\text { memudahkan } \\
\text { ketua jurusan } \\
\text { PSTI untuk } \\
\text { mengawasi } \\
\text { pengelolaan aset } \\
\text { di jurusan. }\end{array}$ \\
\hline $\begin{array}{l}\text { Penjadwalan } \\
\text { kegiatan } \\
\text { maintenance } \\
\text { dan stok } \\
\text { opname }\end{array}$ & $\begin{array}{l}\text { Belum ada } \\
\text { penjadwalan } \\
\text { kegiatan } \\
\text { maintenane } \\
\text { dan stok } \\
\text { opname aset }\end{array}$ & $\begin{array}{l}\text { Sistem informasi } \\
\text { manajemen aset } \\
\text { dapat } \\
\text { menjadwalkan } \\
\text { kegiatan seputar } \\
\text { manajemen aset } \\
\text { sesuai dengan } \\
\text { jadwal yang } \\
\text { disediakan }\end{array}$ \\
\hline
\end{tabular}

\section{Kesimpulan}

Dari proses identifikasi yang dilakukan, berikut gambaran proses manajemen aset yang sedang berjalan di PSTI

- Pendataan aset menggunakan spreadsheet excel.

- Data aset yang ada sudah usang dan pembaruan data sudah lama tidak berjalan.

- Nomor Inventaris banyak yang hilang maupun tidak terpasang.

- Belum ada pendataan terkait barang habis pakai dan barang laboratorium.

- Sulit untuk melakukan penelusuran aset.

Dari perancangan sistem baru yang telah dilakukan, sistem tersebut dapat melakukan efisiensi di beberapa sektor, antara lain:

- Sistem baru menggunakan website sebagai sarana pengelolaan aset sehingga database akan tersimpan secara online dan realtime.

- Pendataan barang inventaris dan barang habis pakai secara rinci dapat memudahkan penelusuran aset.

- Proses pelaporan data aset dapat dilakukan dengan mudah sesuai dengan kategori yang dibutuhkan.

- Pengawasan dari ketua jurusan dapat dilakukan secara langsung melalui sistem baru.

Sistem informasi manajemen aset berbasis website yang telah dibangun perlu diterapkan untuk mengatur proses kegiatan manajemen aset di PSTI karena dengan sistem yang baru tersebut akan membuat proses pengelolaan, pengontrolan dan penelusuran aset menjadi lebih mudah. 


\section{Daftar Pustaka}

Bin Ladjamudin, A.B. 2005. Analisis dan Desain Sistem Informasi. Graha Ilmu. Tangerang.

Belanger, F., and Slyke, C. V. 2012. Information Systems for Business. John Wiley \& Sons. New York.

FASB. 1980. Statement of Financial Accounting Concepts Volume 3, Nomor 5. Stamford. Connecticut.

Fathansyah.2002. Basis Data. Elex Media Komputindo. Bandung.

Jogiyanto. 2005. Analisis dan Desain. ANDI. Yogyakarta.

Oetomo, B.S.D. 2002. Perencanaan dan Pembangunan Sistem Informasi. Andi Offset. Yogyakarta.

Reyes, A.I. 2015. Implementation of an Asset Management and Maintenance System for the College of Information and Communications Technology. International Journal of Innovation and Applied Studies. 12.2. Hal. 418-423.
Rainer Jr., R. K., and Cegielski, C. G. 2013. Introduction to Information Systems. John Wiley \& Sons. Singapore.

Setiabudi, D.H., Rahardjo,A.S. 2002. Aplikasi ECommerce www.komputeronline.com Dengan Menggunakan Mysql Dan Php4. Jurnal Informatika. 3.2. Hal. 88-95.

Valacich, J.S., Joey F.G., and Jeffrey A.H. 2004. Essentials of Systems Analysis and Design Second Edition. Prentice Hall. New Jersey.

Republik Indonesia. 2010. Peraturan Pemerintah Nomor 71 Tahun 2010 tentang Standar Akuntansi Pemerintah.

-http://www.digital-sense.net/sistem-informasimanajemen-aset-inventori-logistik diakses pada 2 Agustus 2015. Hartono. Sistem Informasi Manajemen Aset / Inventory Logisitk. 